\title{
Acute phase response in cerebral infarction
}

\author{
J SYRJÄNEN, * A-M TEPPO, $†$ V V VALTONEN, $\ddagger$ M IIVANAINEN,§ C P J MAURY $†$ \\ From: *Department of Bacteriology and Immunology, University of Helsinki, the $\dagger$ Fourth Department of \\ Medicine, $\ddagger$ Second Department of Medicine and the §Department of Neurology, Helsinki University Central \\ Hospital, Finland
}

SUMMARY The serum concentrations of the acute phase proteins, C-reactive protein, serum amyloid A protein, and $\alpha-1$-antichymotrypsin were determined in 50 young and middle aged patients with cerebral infarction and in sex and age matched community controls. Of 46 case control pairs, 11 cases but only one control had raised acute phase protein concentrations simultaneously $(\mathrm{p}<0.01)$; four case control pairs were excluded because of an infectious complication following infarction and an acute phase response. Seven of the 11 patients $(64 \%)$ with raised acute phase protein concentrations had a history of bacterial infection in the preceding month but of the remaining 35 patients without raised concentrations only four $(11 \%)$ had such a history $(p<0.01)$. In general, the acute phase response was less pronounced and occurred less often than has been reported in patients after acute myocardial infarction.

The results suggest that a positive acute phase response is associated with a preceding bacterial infection or with an infectious complication after cerebral infarction. Measurement of acute phase proteins, therefore, could be used to evaluate the possible role of preceding bacterial infection in the development of cerebral infarction and also in the management of these patients as an early indicator of possible infectious complications.

The acute phase response occurs following a wide variety of different forms of infection, inflammation, or tissue damage. In the acute phase response the concentrations of several plasma proteins increase, including the proteinase inhibitors $\alpha$-1-antitrypsin and $\alpha$-1-antichymotrypsin, C-reactive protein, serum amyloid A protein, ceruloplasmin, $\alpha$-1-acid glycoprotein, fibronectin, and various coagulation, complement and transport proteins.' Infections of both bacterial and viral origin cause the acute phase response..$^{2-7}$ The $\mathrm{C}$ reactive protein concentration, however, is usually higher in bacterial than in viral infections. Thus measurement of $\mathrm{C}$ reactive protein concentration has been used in differentiating between bacterial and viral infections. ${ }^{2367}$ Inflammation and tissue damage following ischaemic necrosis in myocardial infarction has also been reported to induce the acute phase response. $C$ reactive protein ${ }^{8-10}$ and serum amyloid $A$ protein concentration ${ }^{11}{ }^{12}$ increase in myocardial infarction and are related to the extent of tissue injury. ${ }^{8-12}$ The acute phase response occurring in cerebral infarction is poorly delineated.

Accepted for publication 21 July 1988
We have reported previously that the prevalence of bacterial infections in the month preceding cerebral infarction is significantly higher in young and middle aged patients than in their sex and age matched community controls. ${ }^{13}$ The purpose of the present study was to evaluate the acute phase response following cerebral infarction in these patients by measuring the concentrations of three different acute phase proteins, C-reactive protein (CRP), serum amyloid A protein (SAA), and $\alpha$-1-antichymotrypsin (ACT). We also compared the stroke patients with those without a history of prior bacterial infection to discover indicators of preceding bacterial infections which might possibly trigger thrombus formation and hence cerebral infarction.

\section{Patients and methods}

All consecutive patients under 50 years of age admitted to the Helsinki University Central Hospital between June 1985 and August 1986 with diagnosed ischaemic cerebral infarction were studied as described earlier. ${ }^{13}$ The whole series included 54 patients. Cerebral infarction was diagnosed on the basis of computed tomography findings on admission (43 
cases), or if these were normal, on symptoms and signs suggesting cerebral infarction and lasting more than 24 hours in the absence of other aetiologies of focal symptoms ( 11 cases). In 52 patients ( 31 men and 21 women) we had enough sera for measurement of CRP and in 50 patients ( 29 men, 21 women) for SAA and ACT measurements as well. The mean age of the patients was 38 years (range 17 to 49 years). In the 52 patients whose CRP was studied the infarction occurred in the distribution of the medial cerebral arteries in 36, of the posterior arteries in five, and of the vertebrobasilar arteries in 11 patients. The controls were matched with patients for sex and age $( \pm$ one year). The controls were selected at random from the official register of the inhabitants of Helsinki, as described in detail in the previous study. ${ }^{13}$

As we have earlier reported bacterial infections were more common in our stroke patients during the month before the onset of stroke symptoms than in their community controls during the month before examination. ${ }^{13}$ In all, 12 patients and two controls had a probable or confirmed (by culture) bacterial infection during the preceding month. Except for one patient, whose sphenoidal sinusitis was diagnosed by computed tomography on admission, the diagnosis of a bacterial infection had been made before the onset of the patient's stroke symptoms or before examination in the controls, either by a general practitioner or by a hospital physician not involved in the present study. In 11 of these 12 patients we had enough sera for acute phase protein assays. The 11 patients, whose symptoms of bacterial infection began before the stroke, included two cases of bacterial endocarditis, three cases of pneumonia, two cases of sinusitis, two cases of otitis media, one of purulent external otitis and one with a urinary tract and concomitant respiratory tract infection. These 11 patients with a preceding bacterial infection are referred to as "infection-related" stroke patients. Four of our stroke patients developed an infectious complication which probably began after the stroke, two had pneumonia, and two an infected decubitus ulcer, both associated with a deep leg vein thrombosis. Our two controls who had had a probable bacterial infection during the previous month had sinusitis and bacterial enteritis.

Blood samples for the acute phase protein assays were taken from the patients at least three times: the first sample (sample I) as soon as possible following the onset of stroke symptoms (during the first 72 hours), the second sample two to three weeks later (sample II), and the third sample three months after the stroke (sample III). In many patients two to three serum samples were also taken during the first 72 hours after the onset of the symptoms: from 16 patients during the first 24 hours; from 31 patients during the next 24 hours ( 25 to 48 hours following the onset of symptoms); and from 31 patients during the 24 hours after that (49 to 72 hours following the onset of symptoms). The highest value observed during the first 72 hours was used as sample I if more than one sample was taken. In twelve patients serial samples were taken at 24 hour intervals during the first 25 to 72 hours following the onset of stroke symptoms. Two blood samples were taken from the controls with an interval of two to three weeks (samples I and II). All sera were kept at $-20^{\circ} \mathrm{C}$ until assayed.

\section{SERUM ACUTE PHASE PROTEIN ASSAYS}

CRP, SAA, and ACT were measured by radial immunodiffusion using commercial monospecific antisera. The following standards were used: CRP reference serum for CRP and reference plasma for ACT (Behringwerke AG, Marburg, West Germany), and pooled acute phase serum for SAA. The concentration of the SAA reference pool was determined by using purified tissue amyloid A protein as standard. The detection sensitivity for both CRP and SAA was $3 \mathrm{mg} / \mathrm{l}$. The interassay coefficients of variation were $6.5 \%$ for SAA $(n=28$, SAA concentration $80 \mathrm{mg} / \mathrm{l})$ and $5.8 \%$ for CRP $(\mathrm{n}=36$, CRP concentration $65 \mathrm{mg} / \mathrm{l})$. In this study acute phase protein values regarded as "positive" are as follows: 10 $\mathrm{mg} / \mathrm{l}$ for CRP, $10 \mathrm{mg} / \mathrm{l}$ for SAA, and $600 \mathrm{mg} / \mathrm{l}$ for ACT (generally accepted limits). We also used higher values as limits for positivity corresponding to the 96th percentile level in our control population after excluding all controls who had had an infection during the preceding month. These higher limits for positivity were as follows: $15 \mathrm{mg} / 1$ for CRP, $30 \mathrm{mg} / 1$ for SAA, and $700 \mathrm{mg} / \mathrm{l}$ for ACT. Limits for highly raised values (above 98th percentile) of CRP, SAA, and ACT are given as $100 \mathrm{mg} / 1,300 \mathrm{mg} / \mathrm{l}$, and $800 \mathrm{mg} / \mathrm{l}$, respectively.

\section{STATISTICAL METHODS}

The non-parametric Wilcoxon signed rank test (two tailed) was used to compare the acute phase values in matched pairs, and the non-parametric Wilcoxon rank-sum test (two tailed) was used to compare the acute phase values in subgroups of patients. The equality of proportions in matched pairs were compared by McNemar's test ${ }^{14}$ or by using exact binomial probabilities ${ }^{14}$ and by the $\chi^{2}$ test with Yates's correction when comparing subgroups of patients. Data with cell frequencies too small for accurate analysis using the $\chi^{2}$ test were analysed using Fisher's exact test.

\section{Results}

CRP values in sample $I$ of the patients and controls and information about related infections are shown in fig 1 . All four patients who had had an infection that 


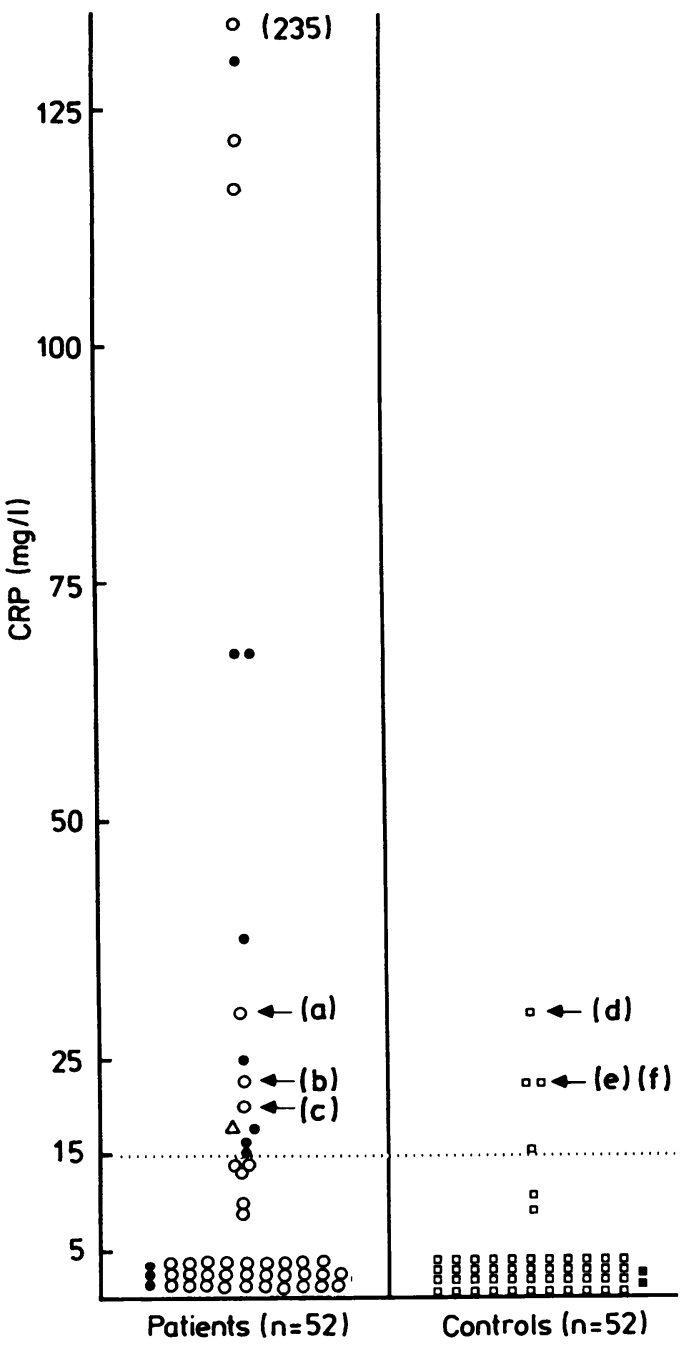

Fig 1 CRP values in sample I of patients and controls with differing histories of infection.

- Infection-related stroke patients; $\Delta$ patients with an infection which probably began after the stroke symptoms; $\bigcirc$ remaining patients; controls with a previous bacterial infection; $\square$ remaining controls. The following cases probably had had an infection before admission (a) preceding febrile respiratory tract infection, ESR $21 \mathrm{~mm} / \mathrm{hour}$; (b) positive streptococcal serology: aDNAseB 1200, ASO

$510 \rightarrow 380 \rightarrow 260$;

(c) preceding enteritis, ESR $24 \mathrm{~mm} / \mathrm{hour}$, positive Yersinia serology: Yersinia $80 \rightarrow 320 ;(d)$ preceding febrile upper respiratory tract infection; $(e)(f)$ preceding upper respiratory tract infection.

probably began after the cerebral infarction had raised CRP values (fig 1). SAA and ACT values in these patients were also considerably increased (SAA $\geqslant 300$ $\mathrm{mg} / \mathrm{l}, \mathrm{ACT} \geqslant 800 \mathrm{mg} / \mathrm{l})$. These four case control pairs, where one patient had an infectious complication early after the stroke and whose positive acute phase response was probably mainly due to this, were excluded from the following analysis. Thus only 46 pairs of case controls (48 pairs for CRP) with no infectious complication beginning after the stroke were studied. The mean values for the acute phase proteins in sample I were higher for the patients than for their controls (table 1). "Infection-related" stroke patients had significantly higher mean values for acute phase proteins than the remaining patients (table 1).

The patients had raised acute phase protein values more often than controls (table 2). The data about associated infections among the cases and controls with raised CRP $(\geqslant 15 \mathrm{mg} / \mathrm{l})$ are given in the legend of fig 1 . Among the 19 patients with raised SAA value $(\geqslant 30 \mathrm{mg} / \mathrm{l})$, there were nine "infection-related" stroke patients, four cases with an associated positive bacterial serology, two cases with a preceding febrile respiratory infection and two cases with a non-febrile upper respiratory infection. Of five controls with raised SAA value one had a preceding febrile upper respiratory infection and three a non-febrile upper respiratory infection. Of the nine patients with a raised ACT value $(\geqslant 700 \mathrm{mg} / \mathrm{l})$, six were "infection-related" stroke patients and one had a preceding febrile respiratory infection. One of the two controls with raised ACT values had a preceding febrile upper respiratory infection.

Table 3 shows the distribution of positive acute phase protein values in the patients' sample I according to evidence of bacterial infection in the

Table 1 Mean values of acute phase proteins ( $\mathrm{mg} / \mathrm{l}$ ) in cases and controls (sample I)

\begin{tabular}{|c|c|c|c|}
\hline & $\begin{array}{l}\text { Cases } \\
\text { Mean (SD) }\end{array}$ & $\begin{array}{l}\text { Controls } \\
\text { Mean (SD) }\end{array}$ & $\begin{array}{l}\text { p Value } \\
\text { (Cases v } \\
\text { controls) }\end{array}$ \\
\hline $\begin{array}{l}\text { CRP: } \\
\text { All (48 pairs)* } \\
\text { Group A (11 pairs) } \dagger \\
\text { Group B (37 pairs) } \ddagger \\
S A A .\end{array}$ & $\begin{array}{l}11(23) \\
35(40)++ \\
5(7)\end{array}$ & $\begin{array}{l}3(6) \\
3(7) \\
3(6)\end{array}$ & $\begin{array}{l}<0.01 \\
<0.02 \\
=0.2\end{array}$ \\
\hline $\begin{array}{l}\text { All (46 pairs)* } \\
\text { Group A (11 pairs) } \dagger \\
\text { Group B (35 pairs) } \ddagger \\
A C T:\end{array}$ & $\begin{array}{l}74(173) \\
233(308)^{* *} \\
23(31)\end{array}$ & $\begin{array}{l}26(83) \\
35(79) \\
22(85)\end{array}$ & $\begin{array}{l}<0.01 \\
=0.08 \\
<0.01\end{array}$ \\
\hline $\begin{array}{l}\text { All (46 pairs)* } \\
\text { Group A (11 pairs) } \dagger \\
\text { Group B ( } 35 \text { pairs) } \ddagger\end{array}$ & $\begin{array}{l}584(306) \\
899(470) \dagger+ \\
485(130)\end{array}$ & $\begin{array}{l}426(120) \\
382(110) \\
439(121)\end{array}$ & $\begin{array}{l}<0.01 \\
<0.01 \\
=0.10\end{array}$ \\
\hline
\end{tabular}

* Four case control pairs, in which one patient had had an infection which probably began after the stroke, are excluded.

tGroup $A$ included 11 cases who had had a probable or definite bacterial infection during the month preceding the stroke and their sex and age matched controls.

†Group B included cases who had not had a probable or definite bacterial infection in the month before the stroke and their sex and age matched controls.

$++p<0.001$, if compared with group B cases.

$* *_{p}<0.01$, if compared with group $B$ cases. 
Table 2 Raised acute phase protein values (mg/l) in case control pairs (sample I)

\begin{tabular}{|c|c|c|c|c|c|c|}
\hline & $C R P$ & $\begin{array}{c}48 \text { pairs) } \\
\text { p Value }\end{array}$ & * $S A A$ & $\begin{array}{c}46 \text { pairs })^{*} \\
\text { pValue }\end{array}$ & $A C$ & $\begin{array}{l}46 \text { pairs })^{*} \\
\text { pValue }\end{array}$ \\
\hline $\begin{array}{l}\text { Limits: } \dagger \\
\text { No of cases } \\
\text { No of controls }\end{array}$ & $\left.\begin{array}{r}\geqslant 10 \\
15 \\
3\end{array}\right\}$ & $<0.01$ & $\left.\begin{array}{r}\geqslant 10 \\
30 \\
9\end{array}\right\}$ & $<0.001$ & $\left.\begin{array}{r}\geqslant 600 \\
15 \\
4\end{array}\right\}$ & $<0.05$ \\
\hline $\begin{array}{l}\text { Limits: } \ddagger \\
\text { No of cases } \\
\text { No of controls }\end{array}$ & $\left.\begin{array}{r}\geqslant 15 \\
11 \\
3\end{array}\right\}$ & $<0.05$ & $\left.\begin{array}{r}\geqslant 30 \\
19 \\
5\end{array}\right\}$ & $<0.01$ & $\left.\begin{array}{l}\geqslant 700 \\
9 \\
2\end{array}\right\}$ & $=0.07$ \\
\hline $\begin{array}{l}\text { Limits: } \dagger \dagger \\
\text { No of cases } \\
\text { No of controls }\end{array}$ & $\left.\begin{array}{l}\geqslant 100 \\
1 \\
0\end{array}\right\}$ & N.S. & $\left.\begin{array}{l}\geqslant 300 \\
3 \\
1\end{array}\right\}$ & N.S. & $\left.\begin{array}{l}\geqslant 800 \\
5 \\
0\end{array}\right\}$ & $<0.05$ \\
\hline
\end{tabular}

*Four case control pairs, in which patients had had an infection which probably began after the stroke, are excluded.

tGenerally accepted limits for positivity.

596th percentile limits for positivity obtained from the control population.

†98th percentile limits for highly raised values.

month preceding the stroke. "Infection-related" stroke patients had a positive acute phase response significantly more often than the remaining patients (table 3). When "infection-related" stroke patients were excluded from table 2 the significant difference between cases and controls disappeared for CRP and ACT and was found only for SAA when using the lower limit for positivity.

All three acute phase protein values were simultaneously positive (generally accepted limits) more often in cases than in controls (table 4). Again, this was a more common feature in the "infection-related" stroke patients than in the remaining patients. When case control pairs with an "infection-related" stroke patient were excluded no difference was observed between the patients and their controls in the remaining pairs.

Nine of the 11 "infection-related" stroke patients still had symptoms of an infection when their symptoms of cerebral infarction began. Two controls who had had a bacterial infection during the preceding

Table 3 Raised acute phase protein values ( $\mathrm{mg} / \mathrm{l}$ ) in patients' sample I, according to evidence of infection in month preceding stroke*

\begin{tabular}{|c|c|c|c|c|c|c|}
\hline & $C R P$ & p Value & $S A A$ & p Value & $A C T$ & p Value \\
\hline $\begin{array}{l}\text { Limits: } † \\
\text { Group A } † \\
\text { Group B } \dagger \dagger\end{array}$ & $\left.\begin{array}{l}\geqslant 10 \\
8 / 11 \\
7 / 37\end{array}\right\}$ & $<0.01$ & $\left.\begin{array}{c}\geqslant 10 \\
9 / 11 \\
21 / 35\end{array}\right\}$ & NS & $\left.\begin{array}{l}\geqslant 600 \\
8 / 11 \\
7 / 35\end{array}\right\}$ & $<0.01$ \\
\hline $\begin{array}{l}\text { Limits: }{ }^{* *} \\
\text { Group A† } \\
\text { Group B }+\dagger\end{array}$ & $\left.\begin{array}{l}\geqslant 15 \\
8 / 11 \\
3 / 37\end{array}\right\}$ & $<0.001$ & $\left.\begin{array}{c}\geqslant 30 \\
9 / 11 \\
10 / 35\end{array}\right\}$ & $<0.01$ & $\left.\begin{array}{l}\geqslant 700 \\
6 / 11 \\
3 / 35\end{array}\right\}$ & $<0.01$ \\
\hline
\end{tabular}

*Four patients, who had an infection which probably began after the stroke, are excluded.

tGroup $A$ included 11 infection-related stroke patients.

+ Group B included patients who had not had a probable or definite bacterial infection in the month before the stroke.

tGenerally accepted limits for positivity.

**96th percentile limits for positivity obtained from the control population. month were already healthy at the time of the examination. The patients who still had symptoms of bacterial infection at the onset of stroke had raised CRP, SAA, and ACT values significantly more often than patients without symptoms of bacterial infection (CRP $\geqslant 15 \mathrm{mg} / \mathrm{l}$, eight of nine $v$ three of 39 , respectively, $\mathrm{p}<0.001$; SAA $\geqslant 30 \mathrm{mg} / \mathrm{l}$, eight of nine $v 11$ of 37 , respectively, $\mathrm{p}<0.01 ; \mathrm{ACT} \geqslant 700 \mathrm{mg} / \mathrm{l}$, six of nine $v$ three of 37, respectively, $\mathrm{p}<0.001$ ). All three acute phase protein values were positive in seven of the nine patients with symptoms of bacterial infection but in only four of the remaining patients (seven of nine $v$ four of 37, p $<0.001$ ). The four patients who had all three acute phase protein values raised, but who had no associated history of probable or confirmed (by culture) bacterial infection, included one patient from whom a reliable history of infection could not be obtained due to aphasia. It could not be obtained from his relatives either. Furthermore, one of these four patients also had a slightly raised erythrocyte sedimentation rate (ESR) and another had positive streptococcal serology. The third patient had had a febrile respiratory tract infection with cough during the preceding month and was found to have raised ESR. The fourth patient had a history of non-febrile upper respiratory tract infection during the preceding month.

Serial CRP values in 12 patients are shown in fig 2 . CRP values in "infection-related" stroke patients were higher than in the other patients. The patient who got pneumonia after the stroke showed a pronounced CRP response.

No significant difference was found in the number of patients who had positive acute phase values (generally accepted limits), when patients with medial cerebral artery infarction were compared with those with vertebro-basilar artery infarction (CRP 10 of $33 v$ four of 10 , respectively, $\mathrm{p}>0.80$; SAA 23 of $31 v$ four of 10 , respectively, $\mathrm{p}>0 \cdot 10$; ACT 11 of $31 v$ three of 10 , respectively, $p>0.95$ ). The incidence of medial

Table 4 All measured acute phase protein values positive* in 46 case-control pairs $\dagger$ (sample I) and in corresponding patients, according to history of infection

\begin{tabular}{|c|c|c|}
\hline & $\begin{array}{l}\text { All values } \\
\text { positive* }\end{array}$ & p Value \\
\hline $\begin{array}{l}\text { No of cases } \\
\text { No of controls } \\
\text { No of patients in Group } A \ddagger(N=11) \\
\text { No of patients in Group } B+t(N=35)\end{array}$ & $\left.\begin{array}{l}11 \\
1 \\
7 * * \\
49\end{array}\right\}$ & $\begin{array}{l}<0.01 \\
<0.01\end{array}$ \\
\hline
\end{tabular}

${ }^{*} \mathrm{CRP} \geqslant 10 \mathrm{mg} / \mathrm{l}, \mathrm{SAA} \geqslant 10 \mathrm{mg} / \mathrm{l}, \mathrm{ACT} \geqslant 600 \mathrm{mg} / \mathrm{l}$.

tFour case control pairs, in which one patient had had an infection which probably began after the stroke, are excluded.

tGroup A included 11 "infection-related" stroke patients.

+ Group B included 35 patients who had not had a probable or definite bacterial infection in the month before the stroke.

* If compared with controls, $p<0.01$.

qIf compared with controls difference is not significant ( $p>0.3$ ). 


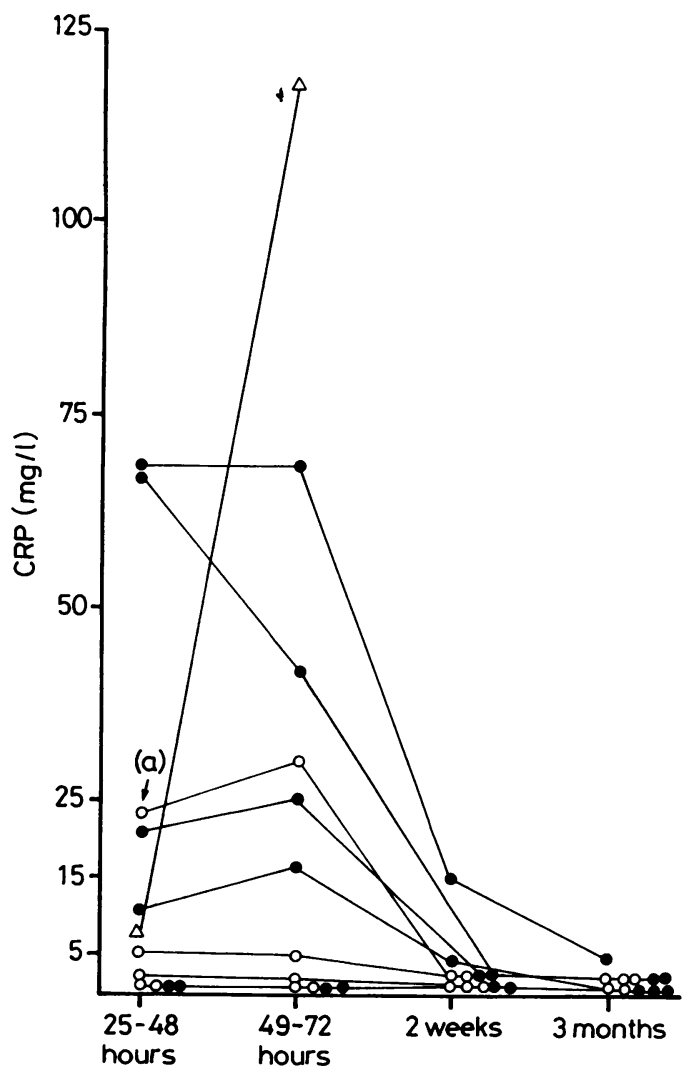

Fig 2 CRP values in serial samples from 12 patients with differing histories of infection

- Patients with a preceding probable or definite bacterial infection; $\triangle$ patient who got pneumonia after the stroke; $\bigcirc$ remaining patients; (a) this is the same patient as (a) in fig 1 .

cerebral artery or vertebro-basilar artery infarction also did not differ among "infection-related" stroke patients or among remaining patients.

\section{Discussion}

This study shows that acute phase response after cerebral infarction is less common and weaker than that reported after myocardial infarction. ${ }^{8-12}$ Almost all patients with myocardial infarction have been reported to have CRP and SAA concentrations above the generally accepted limits. ${ }^{8-12}$ Peak CRP concentrations exceeded $100 \mathrm{mg} / \mathrm{l}$ in $50 \%$ to $70 \%$ of patients with myocardial infarction, ${ }^{910}$ and SAA concentrations exceeded $300 \mathrm{mg} / \mathrm{l}$ in $50 \%$ of patients. ${ }^{12}$ Corresponding figures in our patients without infectious complications following stroke were $2 \%$ and $7 \%$, respectively. Patients who had had a bacterial infec- tion during the month preceding the cerebral infarction had significantly higher concentrations of acute phase proteins than those without such a history or the controls. Furthermore, patients who had an infectious complication after stroke showed a pronounced acute phase response.

CRP and SAA values are known to reach their peak during the third day after the onset of symptoms in myocardial infarction. ${ }^{91012}$ In our study samples were taken during the third day after onset of symptoms in $60 \%$ of the patients. Peak values were therefore probably recorded in most of the patients. Furthermore, fig 2 shows that there is no remarkable increase in values measured during the second and third day after onset of symptoms.

For myocardial infarction it has been reported that the CRP and SAA responses relate to the extent of tissue damage. ${ }^{8-12}$ In cerebral infarction the association between acute phase response and the extent of infarction has not been studied. As the acute phase response did not show any significant difference between patients with medial cerebral artery infarction (usually extensive tissue damage) and those with vertebrobasilar infarction (usually little tissue damage) in our study, it is not very likely that the acute phase response relates directly to the extent of cerebral infarction.

In all patients and in all except one control with CRP values above the limit (fig 1) infection could explain the increased values found, either in the history or laboratory test results. According to the results in tables 2 and 3 and associated data about preceding infections in patients and controls, it seems likely that the increases in CRP and ACT values are most often a result of a preceding bacterial infection, whereas SAA is probably also increased in mild upper respiratory tract infections of possible viral origin. It has been reported that the SAA concentration rises in patients with a common cold or influenza and even in subjects who are asymptomatic excretors of rhinovirus or influenza virus. ${ }^{5}$ Slight increases in SAA concentrations in our patients could also have been a result of the tissue damage of cerebral infarction. It has previously been shown that SAA is a more sensitive indicator than CRP of tissue injury and inflammation ${ }^{15}$ and non-infectious conditions characterised by normal CRP and raised SAA concentrations have been described. ${ }^{1516}$

The positive acute phase response could be explained to a great extent by the occurrence of preceding probable or confirmed bacterial infections. The four patients who had all three acute phase protein values increased (table 4 ) might actually have had a bacterial infection, although the diagnosis of bacterial infection had not been verified. Such an explanation for the increased values in these four is 
supported, at least in one patient, by the positive streptococcal serology.

One explanation for why the "infection-related" stroke patients had higher acute phase protein concentrations than the remaining patients is the fact that most of these patients (nine of 11) still had some symptoms of infection when they had the stroke. Thus they had not yet entirely recovered from their infection. The possibility cannot be excluded that the patients who showed a positive acute phase response after the stroke had their infarction, for instance, because of a local vasculitis triggered by the preceding infection, and that the acute phase response in these cases may have been related to vascular inflammation. On the other hand, it has been reported that aggregated CRP can aggregate platelets if they are otherwise challenged and may also potentiate platelet activation. ${ }^{17}$ Thus CRP may also have a role in thrombogenesis.

If a patient does not have cerebral infarction associated with a preceding bacterial infection the acute phase response is modest. Raised concentrations of all acute phase proteins (table 4) are highly suggestive of a preceding bacterial infection, which may be related to the aetiopathogenesis of the cerebral infarction. A pronounced rise in the concentration of acute phase proteins during the recovery from a stroke is a good indicator of an infectious complication. Measurement of acute phase proteins could therefore be used to investigate the possible triggering factors of a stroke and for following the recovery of a stroke patient to recognise infectious or other complications.

This study was supported by grants from the Finnish Cultural Foundation, the Finnish Medical Society Duodecim, the Hoechst-Fennica Research Foundation, and the Orion Corporation Research Foundation to JS, and in part by a grant from the Sigrid Juselius Foundation to CPJM.

\section{References}

1 Pepys MB, Baltz ML. Acute phase proteins with special reference to $C$-reactive protein and related proteins (pentaxins) and serum amyloid A protein. Adv Immunol 1983;34:141-212.

2 McCarthy PL, Frank AL, Ablow RC, Masters SJ, Dolan TF. Value of the C-reactive protein test in the differentiation of bacterial and viral pneumonia. J Pediatr 1978;92:454-6.

3 Peltola HO. C-reactive protein for rapid monitoring of infections of the central nervous system. Lancet 1982;i:980-3.

4 Cooper EH, Forbes MA, Hambling MH. Serum beta-2microglobulin and $\mathrm{C}$-reactive protein concentrations in viral infections. J Clin Pathol 1984;37:1140-3.

5 Whicher JT, Chambers RE, Higginson J, Nashef L, Higgins PG. Acute phase response of serum amyloid A protein and Creactive protein to the common cold and influenza. J Clin Pathol 1985;38:312-6.

6 Kerttula Y, Leinonen M, Koskela M, Mäkelä PH. The aetiology of pneumonia. Application of bacterial serology and basic laboratory methods. J Infection 1987;14:21-30.

7 Putto A, Ruuskanen O, Meurman O, et al. C reactive protein in the evaluation of febrile illness. Arch Dis Child 1986;61:24-9.

8 Smith SJ, Bos G, Esseweld MR, van Eijk HG, Gerbrandy J. Acute phase proteins from the liver and enzymes from myocardial infarction; a quantitative relationship. Clin Chim Acta 1977;81:75-85.

9 Kushner J, Broder ML, Karp D. Control of the acute phase response. Serum C-reactive protein kinetics after acute myocardial infarction. J Clin Invest 1978;61:235-42.

10 deBeer FC, Hind CRK, Fox KM, Allan RM, Maseri A, Pepys MB. Measurement of serum C-reactive protein concentration in myocardial ischaemia and infarction. Br Heart $J$ 1982;47: $239-43$.

11 Marhaug G, Hårklau L, Olsen B, Husby G, Husebekk A, Wan H. Serum amyloid A protein in acute myocardial infarction. Acta Med Scand 1986;220:303-6.

12 Shainkin-Kestenbaum R, WinikoffY, Cristal N. Serum amyloid A concentrations during the course of acute ischaemic heart disease. J Clin Pathol 1986;39:635-7.

13 Syrjänen J, Valtonen VV, Iivanainen M, Kaste M, Huttunen JK. Preceding infection as a major risk factor for ischaemic brain infarction in young and middle aged patients. $\mathrm{Br}$ Med $\mathrm{J}$ 1988;296:1156-60.

14 Breslow NE, Day NE. Classical methods of analysis of matched data. In: Breslow NE, Day NE, eds. Statistical methods in cancer research. Vol 1. The analysis of case-control studies. Lyon: IARC, 1980:161-89.

15 Maury CPJ. Comparative study of serum amyloid A protein and C-reactive protein in disease. Clin Sci 1985;68:233-8.

16 Maury CPJ, Teppo A-M. Comparative study of serum amyloidrelated protein SAA, C-reactive protein, and beta-2microglobulin as markers of renal allograft rejection. Clin Nephrol 1984;22:284-92.

17 Fiedel BA. Platelet agonist synergism by the acute phase reactant C-reactive protein. Blood 1985;65:264-9.

Requests for reprints to: Dr Jaana Syrjänen, Department of Bacteriology and Immunology, University of Helsinki, Haartmaninkatu 3, 00290 Helsinki, Finland. 